\title{
Johannesevangeliets tilblivelse
}

\author{
Professor emeritus, dr.phil. et theol. \\ Troels Engberg-Pedersen, Københavns Universitet
}

\begin{abstract}
In discussion with a recent article by Jesper Tang Nielsen on "Åndsforestillinger og deres enhed i Johannesevangeliet" ("Conceptions of Spirit and their Unity in the Gospel of John", Dansk Teologisk Tidsskrift 81, 2018, 18-40), this article addresses three issues: 1) Is it possible, and even necessary, to connect in thought what John says of the pneuma ("spirit") in the three groups distinguished by Tang Nielsen (1. Jesus and the pneuma, with synoptic parallels; 2 . the pneuma and believers, with parallels in Paul and the liturgical practice of the Johannine congregation; 3. the pneuma-"Paraclete", with some parallels in Paul)? The article argues for a positive answer by analysing John 1,32-34 (in context) together with the whole of John ch. 3. 2) Is it possible, and even necessary, to find an important overlap in thought between the socalled "Prologue" of John and the rest of the Gospel? The article argues for a positive answer by analysing John 1,1-18 together with John 12,3536 and 12,44-50. The "Prologue", so it is claimed, is woven into the rest, and the rest could not have been written without it. 3) How should one imagine "John" setting about writing his Gospel? In the light of the answers given to the two previous questions, it is claimed that the best way of doing this is to see "John" as attempting to produce a single, coherent text (John 1,1-20,31) that would build upon and try to articulate the inner coherence of the practice and thought to be found in all its three "predecessors": congregational practice, Paul and Mark.
\end{abstract}

Keywords: Fourth Gospel - pneuma - Synoptic Gospels - Paul - John 1.1-34, 12.35-36, 12.44-50 - origin of John.

\section{Indledning}

Jesper Tang Nielsen har i en fin og tankevækkende artikel, "Åndsforestillinger og deres enhed i Johannesevangeliet”, rejst spørgsmålet om enheden af de forskellige udsagn om pneuma'en ("ånden”) i Johannesevangeliet (herefter JE). Tang Nielsen sondrer mellem tre grupper (Tang Nielsen 2018, 23):

[Gr. 1. Jesus og pneuma:] Man finder én gruppe udsagn, som har tydelige synoptiske paralleller. De omhandler alle Jesu besiddelse af pneuma.

[Gr. 2. Pneuma hos de troende:] Desuden findes én gruppe, som ifølge ordlyden ikke har direkte paralleller i Det Nye Testamente. De har deri- 
mod alle relation til den religiøse praksis i menighederne og har derfor indholdsmæssig sammenhæng med bl.a. Paulus. [Gr. 3. Paraklêtos:] Endelig er der én særlig johannæisk gruppe med paraklêtos-udsagn, som er direkte forbundet med pneuma. Den identificeres som hellig pneuma og sandhedens pneuma.

I lyset heraf konkluderer Tang Nielsen to ting (2018, 19, mine kursiver):

1) De johanneiske udsagn om pneuma og paraklêtos "bekræfter ... ikke umiddelbart, at der ligger én forestilling til grund”. 2) Derimod (Tang Nielsen: "snarere") gælder det, at den johanneiske pneuma-paraklêtos må opfattes som "et resultat af en fortolkningsproces, hvor Johannesevangeliet inddrager forskellige opfattelser af pneuma fra sin Kristus-troende sammenhæng og forsøger at samle dem under én forståelse. Prologen skaber denne enhed, hvis logos forstås filosofisk, som de to nævnte eksegeter [Gitte Buch-Hansen og Troels Engberg-Pedersen] foreslår”.

Tang Nielsens artikel rummer en præcis og i det store og hele overbevisende gennemgang af de forskellige pneuma-steder i JE og deres sandsynlige "oprindelse", i betydningen af forestillinger i den tidlige kristendom forud for Johannes, som han kan antages at have kendt og brugt i udarbejdelsen af sin egen tekst. ${ }^{1}$ Ikke mindst Tang Nielsens påvisning af links tilbage til Paulus og Markus er overbevisende - Paulus i forbindelse med både "gruppe 2"-teksterne (om pneuma hos de troende i menigheden efter Jesu død) og "gruppe 3"-teksterne (om "parakleten") og Markus i forbindelse med "gruppe 1"-teksterne. Ved at sondre på den måde mellem de tre grupper af tekster og samtidig rejse spørgsmålet om, hvorvidt der muligvis ligger én samlet forestilling til grund for dem, har Tang Nielsen brudt ny jord i den internationale forskning: Et tilsvarende forsøg er, så vidt jeg kan se, ikke gjort tidligere. Samtidig er det nok ikke forkert at sige, at Tang Nielsen her i sig selv udvikler den vægt, som to danske forskere, Gitte Buch-Hansen og jeg selv, fornylig har lagt på netop pneuma'en i JE. ${ }^{2}$ Om selve denne tilgang gælder det også, at den (på hver sin forskel-

1. "I det store og hele": Enkelte tekster læser vi forskelligt, jf. senere. Det gælder ikke mindst "gruppe 1"-teksterne om Jesu dåb (1,32-34) og hans "indre liv" (11,33 og 13,21). Omvendt noterer jeg mig med glæde, at vi er helt enige om forståelsen af så centrale tekster som $\mathrm{fx}$ 3,34 og 7,37-39.

2. Se Gitte Buch-Hansen, "It is the Spirit that Gives Life". A Stoic Understanding of Pneuma in John's Gospel (Beihefte zur Zeitschrift für die neutestamentliche Wissenschaft 173; Berlin: De Gruyter 2010) og min egen John and Philosophy: A New Reading of the Fourth Gospel (Oxford: Oxford University Press 2017). (Herefter forkortet: JaP.) 
lige måde) er ny i den internationale forskning. Den kan være forkert eller rigtig. Men der er næppe tvivl om, at den vil blive diskuteret internationalt fremover. ${ }^{3}$ For den, der som jeg er overbevist om enheden i JEs omgang med pneuma'en, er opgaven i en videretænkning af Tang Nielsens læsning indlysende: 1) at vise, at en og den samme pneuma-forestilling ligger til grund på tværs af Tang Nielsens tre grupper, og 2) at vise, at JEs såkaldte "prolog" (1,1-18) ikke kun (muligvis) er skrevet til sidst, men at den er forudsat i hele resten af JE-teksten, og altså må være skrevet (i sin foreliggende udgave) som en indledning til hele resten.

Spørgsmålet om "prologens" forhold til resten er på ingen måde nyt. ${ }^{4}$ For at vise, hvilket felt vi befinder os i, citerer jeg fra tre fremragende eksperter i tiden efter Rudolf Bultmann, nærmere betegnet de seneste 65 år: C.H. Dodd (1953), R.E. Brown (1966) og C.K. Barrett (1978). Brown repræsenterer den periode, hvor man anså "prologen" for at være en oprindelig "hymne", hvortil der var foretaget tilføjelser (fx om Johannes Døberen i 1,6-8 og 1,15). Han siger $(1966,20):^{5}$

$\ldots$ it is perfectly reasonable to recognize that the evidence points to the composition of the Prologue as independent of that of the Gospel ...

Hymne-teorien er i det store og hele forladt, og med god grund, men tanken om "prologen" som en slags "tilføjelse" lever fortsat videre i bedste velgående - måske endda ligefrem hos Jesper Tang Nielsen? I hvert fald ligner hans (og Michael Theobalds) tanke om "prologen" som en "læsevejledning" en hel del, hvad man møder allerede hos C.H. Dodd $(1953,296):^{6}$

3. Min egen bog blev drøftet i "the Johannine Seminar group" ved British New Testament Conference i Maynooth, Irland, 31.8.-2.9.2017 (respondents: Cornelis Bennema og Elizabeth Corsar) og vil tilsvarende blive drøftet i en session under Corpus Hellenisticum in Novum Testamentum ved Society of Biblical Literature's Annual Meeting i Denver, Colorado, 17.-20.11.2018 (respondents: Harold Attridge, Jörg Frey, Judith Lieu og Margaret Mitchell).

4. Sml. Stan Harstine, A History of the Two-Hundred-Year Scholarly Debate About the Purpose of the Prologue to the Gospel of John: How Does Our Understanding of the Prologue Affect Our Interpretation of the Subsequent Text? (Lewiston, NY: Edwin Mellen 2015). Jeg har desværre ikke haft adgang til denne bog. Når jeg sætter "prologen" i "scare quotes", skyldes det moderne forskning om forholdet mellem 1,1-5; 1,1-18; og 1,19-34. Se herfor JaP 40-2.

5. R.E. Brown, S.S., The Gospel According to John, Anchor Bible 29 (New York: Doubleday 1966).

6. C.H. Dodd, The Interpretation of the Fourth Gospel (Cambridge: Cambridge University Press 1953). 
The Logos-doctrine is placed first, because, addressing a public nurtured in the higher religion of Hellenism, the writer wishes to offer the Logos-idea as the appropriate approach, for them, to the central purport of the Gospel, through which he may lead them to the historical actuality of its story, rooted as it is in Jewish tradition, ... ["for frelsen kommer fra jøderne"] (iv.22).

Dodds 1953-bog er efter min mening den bedste bog, man kan læse om JE, selv om man må tage grundlæggende afstand fra hans "platonske" fortolkning. ${ }^{7}$ I det citerede er den implicitte modstilling mellem "Hellenism" (inkl. dens "higher religion"!) og "the historical actuality" af Jesus-historien, som er "Jewish", også dybt problematisk. ${ }^{8}$ Ikke desto mindre har Dodd set den umådelige betydning af netop "the Logos-doctrine" for hele resten, uanset om det så kun skulle være henvendt til "hellenister".

Til sidst kommer den efter min mening mest overbevisende forståelse - som så ofte formuleret af C.K. Barrett $(1978,151)$ : $^{9}$

\begin{abstract}
The Evangelist may have drawn to some extent on existing material - what writer does not? But the Prologue stands before us as a prose introduction which has not been submitted to interpolation and was especially written (it must be supposed) to introduce the gospel - and, it may be added, to sum it up. Many Introductions and Prefaces serve this dual purpose.
\end{abstract}

Bedre kan det ikke siges: "the Prologue stands before us as" osv.

Alt dette kun til indledning. I det følgende vil jeg give et enkelt eksempel på, hvordan en og samme pneuma-forestilling kan ses at ligge til grund på tværs af i hvert fald to af Tang Nielsens tre grupper. Derefter vil jeg give et enkelt eksempel på, hvordan "prologen” kan ses at være forudsat i hele resten. Og endelig vil jeg skitsere, hvilken forskel det gør, om man bliver stående ved Jesper Tang Nielsens billede af JE, eller om man tager det skridt videre, som jeg plæderer for her.

7. Jeg tænker her specielt på hans gennemgang af hele teksten fra A til Z på s. 292443, hvor han i vidt omfang foregreb den senere "narrative" læsning af JE.

8. Bemærk også hos Dodd, at "the Logos-idea" er "the appropriate approach for them", dvs. kun for ikke-jøder. For jøder derimod gælder - "the historical actuality" af Jesus-historien. (Dodd var en fremragende forsker, men hans tro på den direkte historiske aktualitet af, hvad der fortælles om Jesus, var usvækket. Jf. hans senere bog, Historical Tradition in the Fourth Gospel (Cambridge: Cambridge University Press 1963).)

9. C.K. Barrett, The Gospel According to St John (London: SPCK $\left.{ }^{2} 1978\right)$. 
Jesu og de troendes dåb med pneuma $(1,32-34 ; 3,3-8 ; 3,34)$

Vi kan begynde med en central tekst fra gruppe 1: 1,32-34, "dåbsscenen", hvor Johannes Døberen vidner om Jesu modtagelse af pneu$m a$ 'en. Denne tekst er af afgørende betydning. Tang Nielsen viser overbevisende, hvordan Johannes her trækker på Markus. ${ }^{10}$ Han gør meget ud af, at Døberen i JE (modsat hos Markus: Mk 1,9) ikke døber Jesus, men kun vidner om ham. At Døberen skal vidne om Jesus ifølge Johannes, er ganske klart. Men hvad skal han vidne om? Svaret er ikke svært at finde, da det gentages i forskellige udformninger et antal gange i 1,1-34. For det første (1,7-8): Han skal vidne om "lyset", det lys, der ifølge 1,1-5 indgik i den logos, der fra begyndelsen var hos Gud. Samtidig understreges det i 1,8-9, at Døberen ikke selv var det lys, men at han gik forud for det. For det andet $(1,15)$ : Efter at vi har hørt, at logos'en "blev kød" $(1,14)$, vidner Døberen igen om Jesus $(1,15)$ :

Det var ham her, om hvem jeg sagde: Han, som skal komme efter mig, er blevet til forud for mig, for han eksisterede før mig. ${ }^{11}$

Her vidner Døberen altså om Jesus (af kød og blod): at han var den, der skulle komme efter Døberen - men som også var forud for Døberen selv, fordi han eksisterede før ham, nemlig som "lyset" og logos'en. Det er klart, at 1,15 her tjener til at identificere Jesus (som "Jesus lyset" eller "Jesus logos'en" - eller selvfølgelig som "Jesus Kristus", som det bliver til i 1,17) efter "inkarnationen" $(1,14)$, dvs. efter at logos'en blev kød. Hvor 1,6-8 skildrede Døberens vidnesbyrd før Jesu komme (jf. 1,9), dér genoptager og viderefører 1,15 Døberens vidnesbyrd efter hans komme: Det var ham her, jeg talte om. Hvordan skete da det sidste: Hvordan blev logos'en kød?

Det har JE-læserne selvfølgelig brudt deres hoveder med at forstå. Men når man forstår, at det, der følger umiddelbart på "prologen" (1,19-34), hører snævert sammen med "prologen" selv (1,1-18), kan man uden vanskelighed finde svaret. ${ }^{12}$ Her gentages nemlig Døberens vidnesbyrd fra "prologen". Og det sker helt eksplicit $(1,19)$ :

10. Sml. allerede Dodd 1953, 292-3.

11. Hvor jeg ikke markerer oversættelsen med et "DO", er alle oversættelser mine egne.

12. For sammenhængen mellem 1,1-18 og 1,19-34 sml. diskussionen (med referencer) i JaP 40-2. 
Følgende er altså ${ }^{13}$ Johannes' vidnesbyrd, da jøderne i Jerusalem havde sendt nogle præster og levitter til ham for at spørge: "Hvem er du?".

I det følgende gentager Døberen i 1,19-24 eksplicit selv, hvad der i 1,6-8 var blevet sagt $0 m$ ham : at han selv ikke var Kristus, Elias eller "profeten". Da der så i 1,24-28 kommer nogle farisæere og udspørger ham, går han et skridt videre. Farisæerne har spurgt ham om, hvorfor han så døber, når han nu hverken er Kristus, Elias eller "profeten" $(1,25)$. Her bringes altså dåbsmotivet ind i billedet for første gang, hvilket skal vise sig at være meget vigtigt. Døberens svar holder det da også i live (1,26-27):

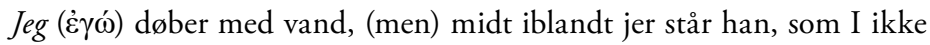
kender, han, som skal komme efter mig ... .

Dette peger tydeligvis fremad. Dels er der en implicit modsætning mellem, at Døberen døber med vand, og at "han, som skal komme," formodentlig vil døbe på en anden måde. Det må man så forvente at høre nærmere om. Dels er "han, som skal komme," åbenbart kun skjult til stede. Man må så forvente, at han senere vil blive åbenbaret.

Begge dele bliver så faktisk opklaret i 1,29-34. "Dagen efter" ser Døberen nemlig Jesus "komme hen imod sig". Her kommer altså den, der skal komme. Og Døberen identificerer (eller om man vil: bevidner) Jesus som "Guds lam" osv. (1,29). Hvad mere er: Døberen gentager i 1,30 lige ud ad landevejen identifikationen af Jesus fra 1,15:

Det er ham her, om hvem jeg sagde: Efter mig skal der komme en mand, som er blevet til forud for mig, for han eksisterede før mig.

Hvornår sagde Døberen det? Svar: i 1,26-27. Thi: 1,30 forholder sig til 1,26-27, ligesom 1,15 (som 1,30 jo ordret gentager) forholder sig til 1,6-8. 1,19-34 er nemlig en udskrift af 1,6-15 om Døberens vidnesbyrd. ${ }^{14}$

Nuvel, hvordan kan Døberen i 1,29-30 nu identificere Jesus på den måde? Nok har han profetiske evner (jf. 1,26-27), og nok er han "udsendt fra Gud" $(1,6)$, men alligevel! Det forklarer Døberen så heldigvis selv med uhørt præcision i 1,31-34. For at forstå gangen i det må

13. Sådan mener jeg det indledende Kaí (egtl. "og”) skal oversættes.

14. Sml. for dette Udo Schnelle, Das Evangelium nach Johannes, Theologischer Handkommentar zum Neuen Testament 4 (Berlin: Evangelische Verlagsanstalt 1998), 47: "Das indirekte Zeugnis des Täufers über Jesus in Joh. 1,19-28 knüpft an 1,6-8 an, das positive Zeugnis in Joh. 1,29-34 nimmt 1,15 auf”. 
vi have med, at Johannes i 1,28 helt eksplicit har tids- og stedfæstet, hvad der skete i 1,24-27 (farisæernes ankomst og spørgsmål):

Dette skete i Betania på den anden side af hinsides Jordan, hvor Johannes døbte.

$\mathrm{Nu}$ er vi altså inde i et konkret, narrativt forløb. Dette videreføres direkte i 1,29, når Johannes skriver "Dagen efter". Kald dette tidspunkt "t4", den narrative nutid. I 1,31ff griber Døberen nemlig tilbage i tid. 1,31: Han "kendte" ham ikke - altså Jesus som "ham, som skal komme"; men han, Døberen, døbte med vand, for at den anden kunne blive åbenbaret for Israel. Dette skete på tidspunktet t1, der klart nok går forud for denne narrative nutid. Her holder man virkelig vejret. Hvad skulle dette vand-døberi dog gøre godt for? Hvordan skulle det kunne bevirke, at "han, som skulle komme," kunne blive åbenbaret for Israel? Men det er så det, Døberen nu kan bevidne (på t4): Han har (på et tidligere tidspunkt: $\mathrm{t} 3$ ) set pneuma'en dale ned som en due fra himlen og forblive over Jesus $(1,32)$. Hvad det betød, forstod han godt, for Gud selv - "han, som har sendt mig for at døbe med vand" - havde forud derfor (ved t 2 ) fortalt ham følgende $(1,33)$ :

Han, over hvem du vil se anden dale ned og forblive over ham, han er den, der døber med hellig ånd.

Døberen kan derfor nu ved $t 4$ bevidne og erklære, at han har set, at "han her er Guds søn" (1,34).

Vi kan opsummere: Døberen var i gang med at døbe - "i Betania, hinsides Jordanfloden" $(1,28)$ - og han var sendt ud (af Gud) for at døbe med vand, for at "han, som skulle komme," kunne blive åbenbaret. På det tidspunkt (t1) kendte Døberen ikke Jesus, men han døbte alligevel. Under dette vand-døberi fortalte Gud så (ved t2) Døberen noget om den person, over hvem pneuma'en ville svæve ned $(1,33)$. Og det skete så (ved t 3 ). Herefter (ved t 4 ) kunne Døberen da i den narrative nutid erklære alt det, han siger om Jesus: "Se her Guds lam osv. (1,29)", "Han her er den, jeg talte om osv. $(1,30)$ ", "Han her er den, der døber med hellig ånd $(1,33)$ ", "Han her er Guds søn $(1,34)$ ". Vi er altså i gang med et omhyggeligt tilrettelagt narrativt forløb. t 1 : Døberen står og døber (1,28-29), for at Jesus kan blive åbenbaret for Israel (1,31). t2: Gud fortæller Døberen, at pneuma'en skal komme ned over en konkret person, som så er den, der døber med hellig pneuma. t3: Gud sender pneuma’en ned over Jesus. t4: Døberen bevidner nu, at disse ting er sket. 
Så kommer der et væsentligt spørgsmål: Det står fast, at Jesus modtager pneuma'en ved denne bestemte lejlighed (nemlig ved t 3 ). Det står også fast, at de nævnte begivenheder sker, mens Døberen står og døber. Giver det hele så nogen som helst mening, hvis det ikke skal betyde følgende? Døberen døber, for at Jesus skal blive åbenbaret som "den, der skulle komme," osv. Og Jesus blev åbenbaret, ved at han blev døbt - selvfølgelig ikke af Døberen (som i øvrigt stod og døbte), men af Gud selv, da han sendte sin pneuma ned over ham, den pneuma, som så også gør Jesus i stand til at døbe "med hellig pneuma". Det er i sidste ende dette, Døberen kan "vidne" om. For han har jo selv set det. Altså: Giver det hele nogen mening, hvis det ikke skulle betyde dette - at Jesus blev døbt med pneuma sendt ned over ham direkte fra Gud? ${ }^{15}$

Man kan så spørge: Spiller det nu virkelig nogen rolle, om Jesu modtagelse af pneuma'en sker i form af en dåb? Hertil er svaret, at det gør det sådan set ikke, hvis spørgsmålet er, hvordan "logos blev kød”. For i betragtning af, hvordan 1,30 direkte gentager 1,15, og hvordan 1,19-34 som helhed er en udskrift af, hvad der er sagt om Døberen i 1,1-18, er det klart, at "logos blev kød", da og ved at Jesus modtog pneuma'en fra oven. ${ }^{16}$ Men stiller man et andet spørgsmål, spiller det faktisk en rolle, om Jesu pneuma-modtagelse skete i form af en dåb. Der er to betragtninger her. Jesper Tang Nielsen ser med rette Jhs 1,29-34 i sammenhæng med skildringen af det samme forløb i Mk 1,9-11. Dér døber Døberen Jesus $(1,9)$, hvorefter himlen åbner sig for Jesus, og der lyder en stemme fra oven til ham (1,10-11). Svarer

15. Kommentatorerne mener gennemgående én af to ting om Jesu dåb: 1) Jesus blev ikke døbt af Døberen. Således fx Andrew Lincoln (Black’s New Testament Commentaries 4; Peabody, Mass.: Hendrickson 2005), 113-14: “That Jesus was baptized by John is suppressed ...”. 2) Jesus blev døbt af Døberen (skal læseren forstå), men det er ikke det, der er det centrale. Således fx Francis J. Moloney (Sacra Pagina 4; Collegeville, Minnesota: Liturgical Press 1998), 53: "The unreported baptism of Jesus by John, motivated by the Baptist's mission to enable the revelation of Jesus to Israel (v. 31), gives substance to the Baptist's witness. ... This revelation has taken place in the unreported event of the baptism of Jesus". Således også Hartwig Thyen (Handbuch zum Neuen Testament 6; 2. udg.; Tübingen: Mohr Siebeck 2015), 122: "Nur als er [der Taufer] Jesus mit Wasser taufte, kann Johannes nach V. 33 gesehen ... haben ..., wie der Geist ... vom Himmel herabschwebte". Så vidt jeg kan se, står jeg ret alene med tanken om, at Jesus skam blev døbt - men af Gud selv. Dette er hverken "unreported" eller "suppressed", men tværtimod bevidnet af Døberen selv.

16. Det følger heraf, at Jesus ikke var hos Gud ved skabelsen (jf. 1,1-2). Logos'en og pneuma'en var det. Og man kan også godt sige, at Jesus Kristus var det (jf. 8,58: "Jeg er, før Abraham blev født", nemlig “jeg”, Jesus, som Jesus Kristus). Hele denne læsning af JE kap. 1 udfoldes og begrundes i interaktion med forskningen i JaP kap. 2, "The Unity of Logos and Pneuma in John 1". 
det så ikke fremragende til Johannes' gennemgående "stramning" af Markus, hvis han flytter Jesu dåb over til at ske ved Guds egen indgriben, og så lader Døberen nøjes med at have en "vidne”funktion (som rigtignok er yderst vigtig: Det er jo på den måde, at Jesus faktisk bliver “åbenbaret for Israel”)? ${ }^{17}$ Sagt på en anden måde: Hos Johannes griber Gud endnu mere direkte ind i forhold til Jesus end hos Markus (hvor man i høj grad kan spørge om, præcis hvilken funktion Jesu åndsmodtagelse og Guds "tilsagn" til ham har). Hos Johannes døber Gud direkte Jesus til hans nye opgave.

At det er sådan, det må forstås, støttes af en central begivenhed senere i JE. I 12,27-28, som er Johannes' gengivelse af Jesu Getsemaneoplevelse, siger Jesus følgende:

»Nu er min sjæl i oprør, og hvad skal jeg sige? Fader, frels mig fra denne time? Nej, det er derfor, jeg er nået til denne time. / Fader, herliggør dit navn!« Da lød der en røst fra himlen: »Jeg har herliggjort det, og jeg vil atter herliggøre det.« (DO, mine kursiver)

Hvor har Gud herliggjort sit navn? Da han "herliggjorde" Jesus. Og hvor og hvordan gjorde han så det? Da han døbte ham med pneuma’en. Det var så at sige begyndelsen, som nu vil blive fuldbyrdet med en ny herliggørelse, som er Jesu opstandelse (og igen, må man tro, foranstaltet af Gud ved pneuma'ens kraft) efter hans død. Fra pneumatisk dåb fra oven til opstandelse til himlen (og igen ved pneuma'ens kraft): Det er forløbet i JE.

Så vidt den første betragtning. Den anden betragtning vedrører hele kap. 3 af JE. Hermed bringer vi også noget stof ind, som hører til Jesper Tang Nielsens gruppe 2 .

Første halvdel $(3,1-22)$ af kap. 3 af JE handler om, hvordan mennesker kan komme til at "se Guds rige" $(3,3)$ og "gå ind i Guds rige" $(3,5)$. Svaret er, at man må blive "født på ny/ovenfra" $(3,3)$ eller "født af vand og ånd (pneuma, 3,5)”. Det er almindeligt anerkendt, at dette handler om den kristne dåb - uden at det jo altså siges eksplicit. ${ }^{18}$ Hvad mere er: Der tænkes på den kristne dåb, sådan som den blev praktiseret af Kristustroende i menighederne efter Jesu død. Jesu død og opstandelse skildres nemlig i 3,13-21 som forudsætning for, at mennesker kan få den "tro", som igen er en forudsætning for, at de kan "få evigt liv" (3,15-16), jf. at "se og gå ind i Guds rige". Alt dette fordrer altså, at de Kristustroende selv modtager pneuma'en i dåben,

17. For forholdet mellem JE og Markusevangeliet se JaP 310-20.

18. Bemærk dette: Der er altså tale om en dåb, hvor pneuma'en modtages, men det siges ikke eksplicit. På samme måde i Jesu tilfælde i 1,32-33. Skyldes "tavsheden" om dåben mon - at det så at sige gav sig selv, at pneuma-modtagelse skete i en dåb? 
ligesom Jesus gjorde det (i en dåb) ifølge kap. 1. Det er svært at se andet, end at Johannes her forudsætter den snævrest tænkelige sammenhæng mellem, hvad han sagde om Jesus i kap. 1, og hvad han nu i kap. 3 siger om såvel de Kristustroende efter Jesu død som om Jesus selv. Det er, fordi Jesus selv blev døbt med pneuma'en og efter sin død vil genopstå (og igen ved pneuma'ens hjælp), at han tillige efter sin egen død og opstandelse kan døbe de Kristustroende til opstandelse og evigt liv. Samtidig gælder det uden tvivl, at kap. 3 som helhed lige præcis afspejler menighedens dåbspraksis og dåbsforståelse i tiden efter Jesu død. Hvad Johannes altså har gjort i kap. 3, er at skildre en (helt usædvanligt fiktiv?) begivenhed, som vi ellers intet kender til, nemlig Nikodemus' natlige møde med Jesus, på en måde, som forudsætter menighedens dåbspraksis, og som så også indskriver den i JEs overordnede forståelse af Jesu egen identitet, skæbne og betydning.

Med henblik på vores senere tema om sammenhængen mellem "prologen" og resten af evangeliet, er det på sin plads lige at nævne, at talen i kap. $3 \mathrm{om}$ at blive "genfødt med vand og pneuma" direkte viderefører, hvad der allerede blev sagt i "prologen” (1,12-13):

Men alle dem, der tog imod ham, gav han kraft ( $(\dot{\varepsilon} \xi o v \sigma i ́ \alpha)^{19}$ til at blive Guds børn, dem, der tror på hans navn; / de er ikke født af blod, ikke af køds vilje, ej heller af mands vilje, men af Gud.

Hvordan gav Gud de Kristustroende denne "kraft"? I dåben, jf. kap. 3. Bemærk også, at "prologens" omtale $(1,14$ og 18) af Jesus som den

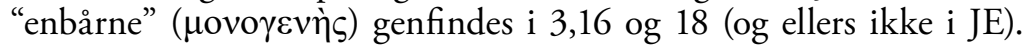
Også det peger i retning af, at disse to tekster ("prologen" og 3,1-22) er vævet snævert ind i hinanden.

Men nu videre i kap. 3. I 3,23-36 indføres så igen ... Johannes Døberen. Han var fortsat i gang med sin dåbsvirksomhed $(3,23)$, da han endnu ikke var kastet i fængsel $(3,24)$. Det sidste hører vi ikke mere om i JE. Men vi kender det jo fra Markusevangeliet (6,14-29). Hos Johannes hører vi så, at Døberens disciple strides "med en jøde" om "renselse" $(3,25)$ og derpå henvender sig til Døberen selv med besked om, at "han, som var hos dig på den anden side af Jordan, han, som du har vidnet om, han døber nu selv" (3,26). Dette er på den ene side en helt klar reference tilbage til 1,1-34 (dels til 1,28, dels til al talen om Døberens “vidnesbyrd” i 1,1-34). På den anden side er det sammen med omtalen af "renselse" i 3,25 er klart vidnesbyrd om, at det hele handler om dåb, men nu altså kristen dåb, som jo også var emnet

19. Den "kraft" (som ikke bare er DOs "ret") er uden tvivl pneuma'en. Det er jo også pneuma’en, der ligger bag resten af de to vers. 
i kapitlets første halvdel (3,1-22). Hvad er det så, Johannes vil sige ved at lade Døberen "vidne" om Jesus endnu en gang?20

Svaret fremgår af 3,31-36. Jesus er kommet ovenfra $(3,31)$. Han vidner om, hvad han har set og hørt dér $(3,32)$. Det vidnesbyrd skal man tage imod (3,33). For Jesus er sendt af Gud og taler Guds ord, da Gud ikke giver (= har givet ham) pneuma'en "efter mål" $(3,34)$. Tværtimod har Gud givet alt i sin søns hånd $(3,35)$, hvilket så betyder evigt liv for den, der tror på sønnen $(3,36) .{ }^{21}$ Hvad alt dette betyder, er hverken mere eller mindre, end at den opgave for Jesus, som skildres så uforglemmeligt i det berømte stykke 3,16-21, blev givet til Jesus, da han modtog pneuma'en. ${ }^{22}$ Med andre ord udfolder kap. 3 i både 3,11-21 og 3,31-36, hvad der var indholdet af Jesu pneuma-modtagelse tilbage i 1,32-34: den opgave, der dermed blev stillet ham.

Men nu så vi også, at kap. 3 hele vejen igennem også handler om dåb: menighedens dåb i 3,3-8 og (må man tro) den kristne dåb (som selvfølgelig også er menighedens) i 3,31-36 modsat jødernes "renselse" og Døberens dåb i 3,25 og 26-30. Dermed bliver det klart, at 3,31-36, som i Døberens egen mund udskriver, hvad han allerede havde sagt i 1,32-34, også handler om, hvordan Jesus (da han fik pneuma'en, 3,34) blev døbt af Gud - nemlig som baggrund (2. halvdel af kap. 3) for den menighedsdåb, der er temaet i kapitlets 1. halvdel (og som der også spilles på i 3,33 og 36). Kort sagt: Formålet med at bringe Døberen ind igen i 2. halvdel af kap. 3 er at begrunde den særlige pneuma-karakter af den kristne menighedsdåb, der har været skildret i kapitlets 1. halvdel, ved at lade Døberen erklære (endnu en gang, jf. 1,24-34), at Jesus har den særlige "kompetence", der skildres i 3,31-32, fordi han blev døbt med pneuma'en af Gud selv (3,34-35). Den kristne menighedsdåb føres dermed tilbage til Jesu egen dåb, den dåb, hvormed Gud både gav Jesus hans helt særlige kompetence og også den opgave, der fulgte med den: at bringe menneskene til en dåbsbaseret tro og dermed give dem evigt liv (jf. 3,33 og 36 og 3,3-8).

Så vidt den anden betragtning til at begrunde vigtigheden af, at Jesu pneuma-modtagelse som skildret i 1,32-34 er at forstå som en regelret dåb fra oven. Betragtningen er følgende: Kun når man for-

20. Bemærk her, at jeg - med langt de fleste nye fortolkere - læser hele 3,27-36 sammen som Døberens tale. (Tidligere har man adskilt mellem 3,27-30 og resten.) Jf. JaP 128-31.

21. (Bemærk i en parentes, hvordan 3,31-36 i virkeligheden stemmer snævert indholdsmæssigt overens med 12,44-50, som vi vender tilbage til. Disse tekster, som dels siger noget centralt om Jesu identitet og skæbne, dels formulerer hele formålet med denne skæbne, udtrykker essensen af JEs budskab.)

22. Det er også som pneuma-modtager, at Jesus "er kommet ovenfra" $(3,31)$, kan vidne om, "hvad han har set og hørt dér" $(3,32)$ og "er sendt af Gud" $(3,34)$. Logos'en blev jo kød, da Jesus blev døbt med pneuma’en. 
står det på denne måde, giver den megen understregning af dåb $\mathrm{i}$ hele kap. 3 sammenhængende mening. Jesu dåb begrunder den kristne menighedsdåb.

Med denne læsning af kap. 3 i sammenhæng med kap. 1 (1,1-34) har jeg forsøgt at vise, at der er en meget tættere sammenhæng mellem stof, der hører til i Jesper Tang Nielsens to grupper 1 og 2, end han umiddelbart lader skinne igennem. En passant har vi også allerede set, at kap. 3 tydeligvis forudsætter "prologen". 1,12-13 i "prologen" foregriber 3,3-8 (som i sig selv hører intimt sammen med resten af kap. 3). Omvendt er 3,3-8 en udskrift af 1,12-13 i "prologen".

Herfra kunne man gå videre til fx følgende tekster for at vise sammenhængen mellem, hvad der siges om Jesus og om menigheden (de Kristustroende): 4,23-24 (om at tilbede Gud, som selv er pneuma, " $\mathrm{i}$ pneuma og sandhed"), 6,63 (om pneuma'en, der "levendegør" - både Jesus og de Kristustroende) og 7,38-39 (om, hvordan de Kristustroende efter Jesu død vil modtage pneuma’en). Men ét eksempel på sammenhængen mellem i det mindste to af Tang Nielsens tre grupper må være nok her. ${ }^{23}$

\section{Sammenhængen mellem "prologen" og resten}

Vi har allerede set, at store dele af kap. 3 (3,3-8, 3,16-21, 3,25-36) forudsætter både "prologen" og 1,19-34. Jeg ville selv være parat til at argumentere for noget lignende for følgende passager i Joh kap. $2-12$ : 5,$33 ; 5,37.38 ; 5,43 ; 6,46 ; 7,29 ; 7,33 ; 8,12-19 ; 8,21-29$; 8,3147 ; 8,48-58; 9,35-38; 10,10; 10,1-21; 10,22-30; 10,31-18; 11,25-26; 11,$52 ; 12,27-33 ; 12,35-36$ og 12,44-50. Tag blot ét eksempel: 8,12 "Jeg er verdens lys" giver ingen mening uden "prologen". Men lad os som et sidste eksempel se på afslutningen af kap. 12: 12,35-36 og 12,44-50, hvor der igen tales om Jesus som "lyset".

I 12,27-32 har vi hørt om Jesu "omvendte" Getsemane-oplevelse (jf. ovf.: Hos Johannes omfavner Jesus sin forestående død), om Guds

23. For Tang Nielsens tredje gruppe, "paraklet”-teksterne, må jeg her desværre nøjes med at henvise til min behandling i Johannesevangeliets klarhed (København: Eksistensen 2017), kapitlet "Johannes 13-17", og JaP, kap. 9, "The Farewell Discourse as Paraklesis (John 13-17)". Én hovedpointe er her, at 13,33-35 udgør en "propositio" (tema-angivelse) for hele talen, som binder a) "parakletens" komme som trøst ved Jesu bortgang (jf. 13,33) sammen med b) en forestilling om pneu$m a$ 'en som den forudsatte kraft, der hjælper de Kristustroende efter Jesu død til at efterleve det nye kærlighedsbud (jf. 13,34-35). Jeg hævder også, at man i lyset af denne dobbelthed kan se den indre sammenhæng mellem afskedstalens fire hovedafsnit: i) $13,36-14,31$,ii) $15,1-16,15$, iii) $16,16-33$ og iv) $17,1-26$. 
svar direkte til Jesus, som de omkringstående opfatter som enten et tordenskrald eller en engels stemme - og så om Jesu eksplicitte konstatering, at det er $n u$, at verden dømmes, og at dens hersker (Satan) skal blive jaget ud (12,31). Når Jesus så er blevet "ophøjet fra jorden" $(12,32)$ - og dermed mente han: "er blevet løftet op på korset" (jf. $12,33)$ - vil han "trække alle mennesker til sig" $(12,32) .{ }^{24}$ Disse forudsigelser reagerer så "skaren" på - og faktisk med stor indsigt (jf. 12,34): Kristus skal jo blive til evig tid! Hvad mener du med, at Menneskesønnen skal ophøjes? Hvem er overhovedet denne Menneskesøn? Når skaren pludselig begynder at tale om "Menneskesønnen", skyldes det, at Jesus indledte sin tale i 12,23 med at sige, at "Timen er kommet, da Menneskesønnen skal herliggøres". Skaren er altså slet ikke dum.

Hvad svarer Jesus da i 12,35-36? Her er teksten:

(35) Jesus sagde til dem: „En kort tid endnu er lyset hos jer. I skal vandre, mens I har lyset, for at ikke mørket skal gribe jer. Den, der vandrer i mørket, ved ikke, hvor han går. (36) Tro på lyset, mens I har lyset, så I kan blive lysets børn.»

Hvordan besvarer det nu skarens forskellige spørgsmål? Det gør det kun ved at forudsætte "prologen". Den "Menneskesøn", der skal "ophøjes", og den "Kristus", der ikke skal "forblive til evig tid" (begge dele fra skarens spørgsmål), er det "lys", hvis færden blev skildret i "prologen". Men det er der altså kun "en kort tid endnu" - underforstået: så skal "Menneskesønnen" "ophøjes" på korset (og videre op i himlen til Gud, i hvis favn han så vil være, jf. 1,18). Dermed er skarens spørgsmål de facto besvaret (selv om de ikke forstod det sagte, jf. 12,37-43). Men Jesus går så i 12,35-36 videre med at fortælle dem, hvordan de skal forholde sig her og nu, mens de har "lyset" hos sig: De skal "vandre" (= leve), ikke blot "mens" de har lyset, men også "sådan som" eller "i overensstemmelse med, at" (ís) de har lyset. Og det skal de gøre, for at ikke mørket skal "gribe" dem. Ordet for

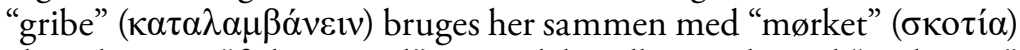
i betydningen "fă bugt med" $\mathrm{i}$ en tydelig tilbagegriben til "prologens" vers 1,5 :

(5) Og lyset skinner i mørket, og mørket greb det ikke. ${ }^{25}$

24. Hvordan mon? Svar: Ved at give dem pneuma'en. Sml. tematikken om at "komme til” Jesus, når Gud har "trukket" en til sig selv i 6,44 og 6,36-45, jf. JaP 161-4. 25. Indrømmet: I 1,5 kan $\kappa \alpha \tau \alpha \lambda \alpha \mu \beta \alpha ́ v \varepsilon ı v$ også betyde "forstod" - og betyder sikkert begge dele, jf. JaP 40 med referencer. 
Genoptagelsen af "prologen" videreføres så i 12,36, når Jesus siger til skaren, at de skal tro på lyset - og igen "sådan som" eller "i overensstemmelse med, at" ( $\dot{\omega} \zeta)$ de har det - for at de kan blive lysets børn. Hvad det drejer sig om, er temaet fra "prologens" vers 1,12-13, som vi

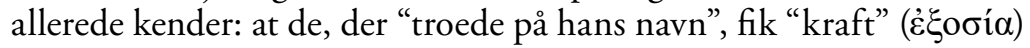
til at blive "Guds børn" osv. Hvad Jesus siger til skaren i 12,36 er da, at de skal tro på lyset, sådan at de på den måde kan blive "(gen)født af Gud" (jf. 1,13) ved at modtage pneuma'en og dermed få evigt liv som "lysets sønner".

Men rejser der sig ikke et problem her? For det første kan menneskene ifølge JE først modtage pneuma'en efter Jesu død (jf. 7,3739). For det andet er skaren fuldstændig uden for rækkevidde af Jesu opfordring til dem om at tro på ham på den måde, der ville bringe pneuma til dem og dermed evigt liv (jf. 12,37-43). Hvorfor siger Jesus så alligevel til dem, at det er det, de skal? Men det er netop pointen: De skulle forstå og tro på Jesus på den måde, som også ville give dem pneuma'en og evigt liv. For alt var så at sige til stede i og med Jesus selv. Men det kunne de blot ikke - hvad Johannes netop på denne måde viser sine læsere. Det er derfor, "Menneskesønnens" død og opstandelse var nødvendig. Først da kunne menneskene nå derhen, hvor de fra først af skulle.

Under alle omstændigheder kan vi konstatere, at 12,35-36, som i sig selv hører snævert sammen med hele 12,23-34, umuligt kunne være skrevet uden "prologen".

Nøjagtigt det samme gælder 12,44-50, som egentlig fortjener en mere udførlig drøftelse. ${ }^{26} \mathrm{Vi}$ kan her nøjes med at kommentere denne sammenhængende tekst i tre afsnit. I 12,44-46 erklærer Jesus først to gange, at hvis man forholder sig til ham selv på den rette måde (ved enten at "tro på" ham, 12,44, eller at "se" ham, 12,45), forholder man sig dermed til "ham, som har sendt mig" (i begge vers). Hvorfor? Hvordan? Det besvares i 12,46, der så at sige skildrer Guds plan bag det hele:

Jeg er kommet ind i verden som lys, for at enhver, som tror på mig, ikke skal forblive i mørket.

Dette vers viderefører selvfølgelig direkte 12,35-36 og dermed også direkte genoptagelsen af "prologen" i det stykke. Da vi jo ved, at den måde, hvorpå de, der tror på Jesus (Kristus), skal blive befriet for at forblive i mørket, er ved at modtage pneuma'en og på den måde opnå evigt liv, er vi på ny tilbage i "prologens" skildring dels af lysets

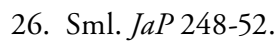


komme til verden, dels af virkningen heraf for dem, der "tog imod" lyset (jf. 1,12-13). 12,46 kunne kort sagt ikke være skrevet uden "prologen".

I 12,47-48 erklærer Jesus så, at hvis man hører hans "ord” ( $\rho \eta ́ \mu \alpha \tau \alpha$, dvs. Jesu "udsagn": hvad han eksplicit siger eller de konkrete "ord", der strømmer ud af hans mund), men ikke holder fast i dem, så bliver man rigtignok dømt - men ikke af Jesus; for han ikke er kommet for at dømme verden, men for at frelse den. Derimod er der så en anden, der dømmer en. Hvem da? Svar: Den logos, som Jesus har talt. Hvilken forskel gør så det? Først må vi lige bemærke, at teksten med sin sondring mellem dom og frelse helt tydeligt genoptager 3,17:

For Gud sendte ikke sin søn til verden for at dømme verden, men for at verden skal frelses ved ham.

$\mathrm{Nu}$ står 3,17 jo ikke et tilfældigt sted, men i en central tekst (3,16-21) om hele formålet med Jesu komme til verden, som i sig selv viderefører "prologen”. Så er det da opsigtsvækkende, at det, der dømmer dem, der ikke hører på Jesu konkrete ord ( $\dot{\rho} \eta \mu \alpha \tau \alpha)$, er - den logos, "som jeg har talt". Hvad Jesus må mene, er, at der bag eller i alle hans konkrete udsagn gemmer sig noget meget mere omfattende, nemlig en hel logos, som så kommer til udtryk $i$ hans konkrete udsagn. Hvilken logos kan det mon være? Svaret er indlysende: den logos, der ifølge "prologen" var hos Gud ved skabelsens begyndelse, og som "blev kød" i Jesus (Kristus). Og hvilken logos er så det? Det er selve Guds plan med at sende Jesus, som den skildres i "prologen": nemlig den gennem Jesus at sørge for, at menneskene kunne få del i det "liv" og det "lys", der var selve indholdet af Guds logos (jf. 1,4: i logos'en "var der liv, og livet var menneskenes lys"). Med den klare sondring i 12,47-48 mellem to ting, som Jesus "taler", nemlig både hans rhêmata og hans logos, viser denne tekst, at den direkte griber tilbage til det centrale begreb i "prologen": den logos, der var hos Gud ved skabelsens begyndelse. ${ }^{27}$ Heller ikke denne tekst kunne kort sagt være skrevet uden "prologen".

Endelig er der 12,49-50, hvor Jesus vender tilbage til tanken fra 12,44-46 om, at han er udsendt af Gud. Nu handler det - i forlængelse af 12,47-48 - om, at det, Jesus taler, kommer direkte fra Gud i

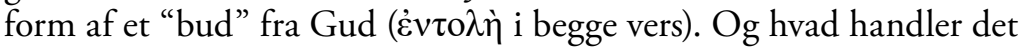

27. Jeg hævder hermed, at den logos, der omtales i 12,48 er identisk med "prologens” logos. Når JEs læsere almindeligvis erklærer, at "prologens” logos ikke genfindes i resten af evangeliet, skyldes det formodentlig, at de opfatter "prologens" logos som en person. Men det var den ikke - før den båret af pneuma'en kom til stede $\mathrm{i}$ Jesus $(1,14+1,32-34)$. 
"bud" så om? Svar: evigt liv $(12,50)$. Igen er vi altså tilbage i "prologen”, ja, man kan faktisk opsummere hele 12,44-50, som følger: lys

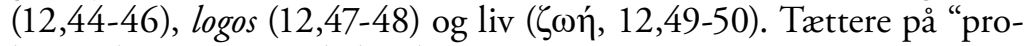
logen" kan man vanskeligt komme.

Jeg har kun givet nogle få eksempler. De har vist, dels at pneu$m a$-ideer, der tilhører mindst to af Jesper Tang Nielsens tre grupper, hører intimt sammen hen over adskillelsen mellem "Jesus alene" og "menigheden (de Kristustroende)"; dels at "prologen" er forudsat i en række centrale tekster i resten af evangeliet. Nu kommer vi så endelig til spørgsmålet om JEs tilblivelse. Hvordan skal man bedst forestille sig tilblivelsen af en tekst, der er gennemsyret af "pneumatiske" motiver på kryds og tværs, og som har centrale ideer i "prologen" vævet ind i sig hele vejen igennem?

\section{Johannesevangeliets tilblivelse}

Der er forskellige muligheder. Første mulighed: Man kan mene (og man har sandelig ment), at JE i al sin besynderlighed oprindelig har været skrevet uafhængigt af i hvert fald "prologen”, måske endda af kap. 1 som helhed. Anden mulighed: Man kan så mene, at "prologen" (og evt. resten af kap. 1?) har været "tilføjet” som en slags smuk indgangsportal, ikke mindst hvis man mener (hvad man igen har ment i store dele af det 20. århundrede), at "prologen" oprindelig var en selvstændig "hymne". Under denne anden mulighed falder måske også Jesper Tang Nielsens (og Michael Theobalds) forslag om at se "prologen" som en "læsevejledning" for hele resten. Tredje mulighed: Man kan også mene, at "prologen” (og resten af kap. 1) og hele resten af JE er konciperet og skrevet i ét stykke. Det sidste udelukker så ikke, at "prologen" også her ses som en slags "læsevejledning".

Den drøftelse, jeg har gennemført i denne artikel, peger klart i retning af den tredje mulighed. Men her er det, at Jesper Tang Nielsens omhyggelige opdeling af pneuma-udsagnene i tre grupper kan føre os videre. Sæt, at "Johannes" ville skrive en ny fortælling om Jesus $i$ lyset af alt, hvad der forelå forud for ham selv. ${ }^{28}$ Der var så - helt centralt - Markusevangeliet. Dets centrale status skyldtes ikke mindst, at det var det første evangelium og dermed udgjorde selve grundlaget for det, "Johannes" nu ville foretage sig. Matthæus og Lukas deri-

28. Jeg skriver "Johannes" om den faktiske forfatter bag teksten, hvem han så var. Min øvrige omtale af Johannes (uden "scare quotes") henviser derimod til den implicitte forfatter i teksten selv. 
mod var snarere at forstå som potentielle konkurrenter. ${ }^{29}$ De havde på hver deres måde gjort, hvad "Johannes" nu ville gøre. Ud over Markusevangeliet var der selvfølgelig også Paulus, som jo havde udarbejdet et samlet koncept for dels Jesu identitet, dels hans betydning for menigheden. Endelig var der en kristen praksis i menigheden, som på forskellig vis så netop var blevet bearbejdet af først Paulus og så Markus.

Hvad kunne "Johannes" så gøre? Han kunne gøre det, han faktisk gjorde: bruge Markusevangeliet som sin grundlæggende strukturelle inspiration, men så udarbejde historier om Jesus, som i deres samlede, overordnede betydning (og her var "Johannes" godt hjulpet af Paulus) gav mening til den konkrete menighedspraksis, som "Johannes" selv kendte til. Helt konkret: I kap. 3 indskriver Johannes dåben fra den kristne menighedspraksis i et samlet koncept, der handler om Jesu grundlæggende identitet, rolle og funktion og så dennes virkning i menigheden (på de Kristustroende). Nøjagtigt det samme gør han i kap. 6, men nu med fokus på nadveren. Osv. osv.

Sæt, at det er sådan, "Johannes” skrev sin tekst. Hvilken rolle spiller det så for os, om det er sådan man skal forestille sig JEs tilblivelse? Svaret er ret enkelt: Hvis det er sådan, det er gået til (og det må altså på forhånd afgøres på de måder, vi har forsøgt at gøre det i denne artikel), får læseren et ekstra skub i retning af at læse selve teksten endnu grundigere end hidtil - og endnu en gang. For hvad den så handler om, er den helt overordnede, store sammenhæng mellem alt, hvad man ("Johannes") dengang ville sige om Jesus, og alt, hvad man dengang ville sige om menigheden i forhold til og i lyset af, hvad man ville sige om Jesus. Med andre ord handler teksten nu om kristendommen som helhed, sådan som den blev oplevet af denne teksts forfatter. Det giver os nogle gevaldige muligheder og nogle gevaldige udfordringer. Vi må nu læse og læse og læse og hele tiden spørge os selv om, hvad denne samlede tekst da siger om den johanneiske kristendom som helhed. Det kan vi kun blive klogere af.

29. Jeg forudsætter her den traditionelle kronologiske rækkefølge af de fire evangelier og ser ikke - som fx kollega Mogens Müller gør det - Lukasevangeliet som det seneste. For en overbevisende drøftelse af problemet se Jesper Tang Nielsen, "Johannes und Lukas. Szenen einer Beziehung," Rewriting and Reception in and of the Bible, FS Mogens Müller, red. J. Høgenhaven, J. Tang Nielsen og H. Omerzu, WUNT 396 (Tübingen: Mohr Siebeck 2018), 125-62. 